\title{
The Rise Ideology of Kiai at State Senior High School Darussholah Singojuruh
}

\author{
${ }^{1}$ Agus Mursidi, ${ }^{2}$ Putu RumawanSalain, ${ }^{3}$ A.A NgrAnomKumbara, \\ ${ }^{4}$ Putu Sukardja \\ ${ }^{1}$ History education, University PGRI of Banyuwangi, Indonesia \\ ${ }^{2}$ Cultural studies, UniversityUdayana, Indonesia \\ ${ }^{3}$ Cultural studies, UniversityUdayana, Indonesia \\ ${ }^{4}$ Cultural studies, UniversityUdayana, Indonesia \\ Corespondingautor: 1 Agus Mursidi
}

\begin{abstract}
This research has the goal to the rise of ideology kiaiat State Senior High School (SMAN) Darussholah in the progress of the implementation of quality education organized by the government. There is a very dominant influence from outside that affects the process of the ongoing education. This study concludes through the analysis that the inclusion of ideology kiaiinterfere with the development of education in SMAN Darussholah to become a professional educational institution. It is necessary for the role of government in providing facilities and infrastructure to achieve professional education institutions. Likewise with the kiai by entering ideology kiai should be able to provide infrastructure such as dormitories and human resources to improve the quality of education in the boarding school.
\end{abstract}

Keywords: ideology, kiai, education.

Date of Submission: 20-01-2018

Date of acceptance: 07-02-2018

\section{INTRODUCTION}

Ideology is a term used to describe the existence of generic ideas that have potential in certain behavior situations. An ideology spreads and works in influencing human behavior, as Terry Eagleton (1991) argues that the spread of an ideology consists of rationalization, universalization, and naturalization. Rationalization is an attempt to give rational-seeming arguments. Universalization is the attempt to present ideas that are universally applicable and necessary everywhere. Meanwhile, naturalization is an attempt to display a belief as something that looks natural. This understanding makes ideology an argument for justifying human behavior. Ideology can be sourced from several aspects of life such as religion, customs, or culture that generally includes politics, economy, and social.Included in the cultural aspects there is a discussion of education. Furthermore, individual knowledge and experience of various aspects of life is internalized resulting in ideology (Tilaar, 2009).

Ideological education concept prepared to give alternative ideas or balancing of the rise of the ideology of education in Indonesia. The existence of kiai in the education system can provide different nuances associated with the process of transformation of science, the relationship between teachers and students who will also affect the surrounding community. Kinloch (1981) when a social or religious paradigm functioned as an ideology, he would have two characters, namely ideology formulated and adhered to by his adherents to achieve certain goals and ideologies used by religious leaders to achieve their political goals. This is a major contribution contributed by religious leaders, namely kiai in the development of education in Indonesia.

Implementation of education in Indonesia is inseparable from the policies made by the government. The role of government towards education is proven by the UUD 1945 Pasal 31 ayat (1) which reads: "Every citizen is entitled to receive instruction; ayat (2) The Government shall undertake and organize a national teaching system regulated by law. The Government also regulates the education policy in Indonesia based on the Undang-UndangRepublikIndonesaiNo. 20 of 2003 on National Education System. The basis of these laws the state has an obligation to build a place of education is used for all the citizens and not for one class only.

Implementation of education in achieving its objectives has been regulated in Undang-Undang No. 20 of 2003 on the National Education System provides guidance on the decentralization mechanism of national education implementation, among others, who is responsible for the management of the national education system, how the national standard of education, who is responsible for the provision of basic, secondary and higher education and so on. What about the schools organized by the state in which the influence of the kiai in 
the process of organizing their education. It is important for the government to know what reality if the education process organized by the government that is influenced by kiai ideology needs some explanation about education climate that happened in the place of education. Educational climate organized by the government that is influenced by kiai will have an impact on principals, teachers, students and guardians. Through this research, it proposes to analyze the rise of kiai ideology in SMAN DarussholahSingojuruh so that the policy makers can evaluate in the implementation of the education of the country that get the influence of the kiai has success, so that can develop the education system. If the education offered has a high competitiveness then the development of education develops very well, has the competitiveness, and the mainstay skills obtained by students. With feedback from principals, teachers, students and school founders to identify whether the results were positive or negative with the rise of kiai ideology at SMAN Darussholah.

\section{REFERENCE THEORY}

\subsection{Kiai Ideology}

According to Gramsci (2013), Ideology is an aspect of "sensationalism" as it was during the period of French materialism in the eighteenth century. The true meaning is "the science of ideas," and because analysis is the only method known and applied by science. Ideology is also understood as ideas, meanings, and practices that claim to be universal truths, a map of meaning that actually sustains the power of certain social groups. On top of that ideology can't be separated from the practical activities of life, but it is a material phenomenon rooted in everyday conditions. Ideology provides the practical behavior of moral guidance compatible with a religion that is secularly understood as the unity of belief between world conception and related action norms (Gramsci, 2013).

Ideology can be said to be the result of thought and belief about power, rights, group goals, all of which determine a behavior perpetrated by a trusting group. Ideology can be sourced from several aspects of life such as religion, customs, or culture that generally includes politics, economy, and social. Included in the cultural aspects there is a discussion of education. Furthermore, individual knowledge and experience of various aspects of life is internalized resulting in ideology (Tilaar, 2009). Storey (2001), in Cultural Theory and Popular Culture also says that ideology is a 'false consciousness'. Ideology in that context is said to be a form of dominant group operation against subordinate groups.

The strengthening of ideology in the generation of the nation is then transformed systematically through educational institutions, especially formal educational institutions with nuances of Islam. On an ongoing basis Islamic education institutions can maintain and maintain the ideological values of Islamic education in the provision of education. The ideology of Islamic education is used to offer change through normative thought processes in the formal education system. Implicitly every thought result follows an ideology that can affect the process of organizing the education system. Elements of Islamic teachings in formal education institutions can not be separated from the involvement of kiai in the education system. It can be seen from the elements in the Islamic education system that includes: kiai, santri, masjid, boarding school, and pengajianbukukuning(soebahar, 2013).

Fadhilah (2011) states that kiai is the most essential feature of a pesantren. Kiai is essentially a title given to a person who has knowledge in the field of religion in this context of Islam. From the point of its function, kiai in Javanese society is divided into into two categories, namely: first, kiai group which is on da'wah and education (al-dakwahwa al-tarbiyah). This group is usually called kiaipesantren or ulama. The role of kiai in the education system becomes central to the activities within an educational institution. Kiai has a comprehensive understanding of religion so that it is not only a scholarly reference for his students but also in the educational environment where the kiai is located, in other words the kiai also become the leader of the social movement in the community.

The word "Kiai" comes from the ancient Javanese "kiya-kiya" which means a respected person (Azizah, 2013: 2). Kiai became one of the strategic elite in society because of his character as a figure who has extensive knowledge and deep on Islamic teachings. Moreover, theologically the kiai are also seen as the heirs of the Nabi (wa-ratsat al-anbiya). It is not surprising that the kiai later became a source of legitimacy from various religions, but also in all aspects of his life (Azizah, 2013: 1). Dierier (2011) in his book entitled "Tradition Pesantren", the term Kiai in Javanese is used for three types of titles are different from each other:

1. Kiai is used as a title of honor for goods that are considered sacred. Kiai Garuda Kencana is used as an eternal "golden train" in Yogyakarta Palace.

2. Kiai is used as a title of honor for the elderly in general.

3. Kiai as a title given by the community to an Islamic religious scholar who owns or becomes the leader of the pesantren and teaches the classical books to his santri. Besides the title of kiai he is also called an alim (a person who is in his Islamic knowledge). 
Judging from the achievement of its political objectives, the kiai have a role in the development of education in pesantren with an approach model that has been going on within their own group by ignoring other groups outside the group (Aly, 2011). The political forces that took place in education became an ideological political struggle between secular nationalists and Islamic nationalists who began to show a change with the tendency of integration of public education institutions and religious education. Based on the explanation of the definition of kiai ideology above, the idea of kiai referred to in this research is the idea or thought given by the person who leads the pondokpesantren and has the expertise in religious science. Kiai is a central element in pesantren life, not only because the kiai is the main buffer of the continuity of the education system in pesantren, but also because the kiai figure is a reflection of the living values in the santri community.

\subsection{Senior High School}

Education is a conscious and planned effort to create an atmosphere of learning and learning process so that learners actively develop their potentials, so that they have personality, intelligence, noble character, and skills needed for themselves and the surrounding community. Education is humanizing human beings, Education is not eliminating human dignity and dignity. Therefore education does not affect the nature of eliminating, because nothing is missing in the education process. Only its nature affects the things that are not good to the good direction and consider the positive potential to be maximal in accordance with its potential (Suyasa, 2005).

Education is a strategic means to improve the quality of a nation. Therefore the progress of a nation can be marked and measured from the progress of education. The progress of some countries in this world is inseparable from the progress that was started and achieved from his education. This was confirmed by Megawati (2002) in Kartono(2008) as follows;

"Education is something that can not be negotiable. Education is the main incandescent of nation-building. The state is obliged to provide and organize facilities and facilities for our children to be able to equip themselves with the greatest possible education. "

So for the development of an advanced nation of education becomes the main capital for the nation's development.Hasbullah (2006) also states;

"Education in the simplest sense is often interpreted as a human effort to foster its personality in accordance with the values in society and culture. But in its development the term education or pedagogy means guidance or help that matures. "

Talk about education is inseparable from the discussion about school. School as a place to learn and teach and receive and give lessons. The schools referred to in this study refer to Pasal18 Ayat (1), (2), and (3) of Law Number 20 Year 2003 regarding Sisdiknas with the formulation that is, the level of education as the continuation of primary and secondary education in the form of Secondary School Top (high school). Different from vocational secondary education, such as Vocational High School (Vocational High School), general secondary education is more directed towards education in the academic field and to continue study in Higher Education.

Law of the Republic of Indonesia no. 20 of 2003 on National Education System in chapter VI article 14 which states that secondary education and general higher education is an education that prioritizes the extension of knowledge required by learners to continue education to a higher level. The intended education is formal, including the curriculum and the assessment is governed by the government. Education policy in the country of Indonesia is always based on national goals and ideals of educating the life of bamgsa listed in the opening of the 1945 Constitution. In the Law No.20 of 2003 article 5, paragraph 5, also explains that every citizen is entitled to the opportunity to improve education throughout life. Thus, education policy is a policy focused on achieving the nation's development goals in the field of education, as one of Indonesia's overall development goals (Barnadib, 2013).

Based on the above description of the state high school education in this study is the teaching and learning activities obtained at secondary education level in formal education in Indonesia conducted after graduating from junior high school (SMP) and held by the government.

\section{METHODOLOGY}

The research design used qualitative descriptive phenomenological method with critical qualitative approach. Qualitative research methods used to understand the phenomenon of what is experienced by the subject of research in a holistic way is described in the form of words of language in a natural special context by utilizing various scientific methods (Moleong, 2012), qualified to achieve two aspects of goals and target. Qualitative research produces descriptive data in the form of words written or oral from the people associated with the problems in research.

In line with Sugiyono (2012), qualitative research method is used to examine an object whose natural condition and researcher as the key instrument to collect triangulation data with the result of research which 
more emphasis on meaning than generalization. Qualitative research in the triangulation paradigm of data to understand the symptoms or phenomena that are natural and reasonable without any manipulation. Furthermore, Sugiyono (2012) states that: "Qualitative researchers as human instruments, functioning to get the focus of research, selecting information as a source of data, collecting data, assessing data quality, analyzing data, interpreting data, and making conclusions on the findings.

The qualitative descriptive method of phenomenological research emphasizes the meaning by explicating the implicit experience structure. Robert C Bogdan and Sari KnoppBiklen (in Mardiyah, 2012), research in phenomenology views means understanding an event in relation to people in certain situations, so as to understand the meaning of human events and interactions, theoretical orientation or theoretical perspective with the phenomenological approach phenomenological approach). Phenomenology focuses on the subjective meaning of objective reality in the consciousness of people directly involved with the problems in this study. Thought, the experience of the research subject becomes important data and the focus of the research problem.

A qualitative method approach is chosen to examine the rise of kiai ideology in the provision of education at SMAN Darussholah which requires a number of actual field data. This research is expected to find as well as describe the data as a whole and intact about the rise of ideology kiai in SMAN Darussholah education. The choice of method is also based on the relevance of the problem studied with a number of primary data from research subjects that can't be separated from their natural background. Qualitative methods have a high adaptability that allows researchers to constantly adjust to situations that change in the data retrieval research.

\section{DATA ANALYSIS}

This research data is taken and completed from the learning process at State Senior High School DarussholahSingojuruhBanyuwangi Regency of East Java State of Indonesia, with principal principals, teachers, students, foundation representatives, and founder pioneers. The data obtained and collected thereafter is analyzed by generating:

\subsection{School Establishment and Licensing Process}

In the statement above implied sentence "no permission, idea of naming, consultation and followed" in the process of admission of new students in the school year 2003/2004 SMAN 1 Darussholah not have operational permission, from sisni seen that in the process of acceptance happened deviation, because pioneer committee have access to the education service so the pioneering committee dare to open the admission of new students. With the proposal sounded SMA NegeriSingojuruh with wet stamp kelembagan. In the proposed operational permit negotiations came the idea to add Darussholah because of its contiguous location to make it look like a collaborative school. Armed with a suggestion from a friend at Kemendiknas, out of operation license on 23 November 2003 with the number of Decree 138 Year 2003. The rise of operational license of SMA Negeri 1 Darussholahmembuaka opportunity that is very big power obtained by kiai so followed by some other educational institutions with using the name of the pesantren.

The kiai and pioneering committees from the beginning in this urain are assumed to be a pillar, in fact consisting of several elements with their respective duties and funcition, it is evident that in the process of purchasing land of educational institutions of SMAN 1 Darussholah the kiai are merely land brokers soil. For matters of payment and excavation of funds to the community as a land buyer assigned to pioneer and school committee. In the description above, SaptoMudito and M. Junaidi show the role and function of the land procurement process and land purchase. The school can only surrender and accept, they do not feel in domination or hegemony kiai. However, after the rise of the kece class the situation is increasingly hegemonic or dominated.

\subsection{Educational quality imaging}

In the statement implied that the brilliant class is a class that is only limited identity in its implementation. So the school is easier in managing the students and distinguish students who are from pesantren and who from regular. But did not rule out that the brilliant word that is understood by the general public is superior.AraHidayat and Imam Mackali argue that the School is an institution engaged in the field of educational services whose activities serve consumers in the form of students so that the general public and students are stakeholders. Marketing ethics in education services is to offer the quality of intellectual service and the overall characterization of the character (2012).

The statement states that the eight classes received by the school are six regular classes and two brilliant classes. But because the place is not possible so the brilliant class must occupy the masjid as a place of teaching and learning process with the pretext of worship to fool guardians who protest. In solving the problem the school finally decided to include all the students in the tenth grade into the afternoon class, resulting in an innovation made by the school to overcome the problem. 


\subsection{Hegemony in education}

In the implementation of curriculum change education process conducted by the school does not violate the existing rules and also does not merukapan religious ministry curriculum sourced from the ministry of national education is adjusted. So, in the implementation of the process of education in school indirectly the principal through his power hegemony education process in SMAN Darussholah for the sake of the continuity of his power which is considered to coexist and bridge the interests of the kiai. Under the pretext of equity a lot of changes that occur in the process of education that took place so many parties who disadvantaged both teachers and students because the learning process is not in accordance with the provisions set by the government both the curriculum and teaching hours.

\section{CONCLUSION}

The rise of kiai ideology in SMAN Darussholah is very basic. Because at the beginning of the establishment of kiai's power play an active role indirectly kiai ideology also plays a role for personal gain and a group of kiai. This theme is related to the rise of kiai ideology at SMAN Darussholah, which disturb the development of the quality of education in SMAN DarussholahSingojuruh. It also affects teachers' motivation to develop a professional and quality education. It is important to understand that this research is looking for alternative solutions to improve education climate in SMAN Darussholah which is influenced by kiai. The shared vision, mission, and open acceptance of kiai ideology will have a positive impact on teaching and learning, teacher motivation and school development in the future. On the other hand to maintain the quality and professionalism of education, the measuring tool that has been determined by the government does not experience changes in the curriculum and hours of learning. The addition of the subjects should coincide with the addition of hours of study. Not only the schools that have to clean up but also the kiai should be able to provide appropriate infrastructure facilities when asking for a quality class as part of a group of kiai. Both wellresourced dormitories and out-of-school education supported by professional faculty to keep pace with the school, so the word brilliant class which is a special class of kiai groups can be excellent students according to their vision and mission to make students who understand the religion. To make this big change requires great courage both from kiai and school groups. The role of government is needed to provide facilities and infrastructure as a support that must be prepared because the establishment of SMAN is adjacent to boarding school is a government program that must be reviewed and fixed, in order to become a superior educational institutions and quality

\section{ACKNOWLEDGEMENT}

On this occasion, the author thanked Prof. Dr. Ir. PutuRumawanSalain, M.Si., As Promoter, and Prof. Dr. A.A. Ngr. AnomKumbara, MA., As the Kopromotor I, and Dr. PutuSukardja, M.Si., as co-supervisor II for their feedback and suggestions to complete this article. Thank you for submitting your scholarship to the writer for a doctor's program at Cultural Studies, Udayana University. A word of appreciation should also be communicated to informants, whose names can not be mentioned one by one for the completion of this article as expected.

\section{REFERENCES}

[1]. Aly, Abdullah. Pendidikanmultikultural di pesantren (telaahterhadapkurikulumpondokpesantren modern islamassalamsurakarta). Yogyakarta: PustakaPelajar. 2011.

[2]. Azizah, Nurul. Artikulasipolitiksantridarikyaimenjadibupati. Yogyakarta.PustakaPelajar. 2013.

[3]. Barnadib, Imam. Filsafatpendidikan. sistemdanmetode. Andi Offset. Yogyakarta. 2013.

[4]. Dhofier, Zamakhsyari.

Tradisipesantren: studitentangpandanganhidupkyaidanvisinyamengenaimasadepanindonesia. Jakarta: LP3ES. 2011.

[5]. E. Terry. Ideologi: an introduktion. London and New York: Longman1991.

[6]. Fadilah, Amir. StrukturdanPolakepemimpinanKyaiDalamPesantren Di Jawa.Hunafa: JurnalStudiaIslamika .Vol 8, No 1 (2011): Pendidikan Islam. IAIN Palu2011.

[7]. Hasbullah.Dasar-dasarPendidikan. Jakarta: Raja GrafindoPersada. 2006.

[8]. Hidayat, imam mackali. PeningaktanMutu madrasah.JurnalPendidikan Islam Volume I nomor.2desember 2012/1434.2012.

[9]. Kartinikartono. Pimpinandankepemimpinan.Jakarta.RajagrafindoPersada.2008.

[10]. Kinloch, Graham C. Ideology and The Social S cience. T.p: Greenwoon Press. 1981.

[11]. Mardiyah. KepemimpinanKiaiDalamMemeliharaBudayaOrganisasi. Malang:Aditya Media Publishing. 2012.

[12]. Moleong, Lexy J. MetodePenelitianKualitatif. Bandung: PT RemajaRosdakarya. 2001.

[13]. Soebahar, Abdul Halim. ModernisasiPesantren; StudiTransformasiKepemimpinanKiaidanSistemPendidikanPesantren. Yogyakarta: LkiS. 2013. 
[14]. Sugiyono. MetodePenelitianKuantitatifKualitatifdan R\&D. Bandung: Alfabeta2012.

[15]. Storey, John. Culture Theory and Popular Culture. London: Pearsons-Prentice Hall. 2001.

[16]. Tilaar, H.A.R. ManajemenPendidikanNasional: KajianPendidikanMasaDepan. Jakarta: RemajaRosdakarya. 2009.

[17]. Undang-UndangRepublik Indonesia Nomor 20 Tahun 2003 TentangSistemPendidikanNasional. Online: http://pendis.kemenag.go.id/file/dokumen.

[18]. Utomo, TeguhWahyu. Antonio Gramsci Prison Notebooks Catatan-catatandaripenjara, Yogyakarta, PustakaPelajar, 2013 (Ed.) Selections from Prison Notebooks. New York: International Publisher.

Agus Mursidi "The Rise Ideology of Kiai at State Senior High School Darussholah Singojuruh." IOSR Journal of Humanities And Social Science (IOSR-JHSS). vol. 23 no. 2, 2018, pp. 66-71. 